\title{
Wrinkles in Time: On the Vagaries of Mi la ras pa's Dates
}

\author{
Andrew Quintman \\ New Haven, USA
}

\begin{abstract}
The dates of Tibet's great eleventh-century yogin Mi la ras pa have long caused confusion. Early literary sources for the yogin's life largely disagree about the year of his birth-frequently listing the animal but not the element of the sexagenary cycle-as well as his lifespan, which ranges from 73 to 88 years. This study identifies the principal traditions for calculating Mi la ras pa's birth, death, and lifespan. In doing so, it illustrates the processes of chronological codification that took place within the yogin's biographical tradition between the twelfth and nineteenth centuries. It begins with a survey of the European and North American scholarship on the yogin's dates and then turns to the primary Tibetan sources to identify three main traditions: 1028-111, 1040-1123, 1052-1035. It concludes with an examination and English translation of a rare chronological analysis carried out by Kah thog Tshe dbang nor bu (1698-1755), who favors the earliest proposed dates.
\end{abstract}

Keywords: Mi la ras pa, Milarepa, chronology, Tibetan calendar, birth year, death year. 


\section{The Problems of Mi la ras pa's Dates}

The dates of Tibet's great yogin Mi la ras pa have long caused confusion. Early literary sources for the yogin's life largely disagree about the year of his birth - frequently listing the animal but not the element of the sexagenary cycle-as well as his lifespan, which ranges from 73 to 88 years. In some ways this parallels the problem of the historical Buddha's dates that has sparked a sub-field of scholarship in its own right. While Tibetan biographers and historians may have differed in their calculations of the yogin's dates, few indigenous authors carried out a detailed investigation of the problem. Early European and North American scholars were similarly confounded, a situation exacerbated by the relative paucity of Tibetan historical sources and early literary works in Mi la ras pa's biographical tradition that were available to them.

This study identifies the principal traditions for calculating Mi la ras pa's birth, death, and lifespan. In doing so, it illustrates the processes of chronological codification that took place within the yogin's biographical tradition. A precise determination of the yogin's birth and death may as yet remain out of reach. However, with the recent discovery of manuscripts and the publication of texts in Tibet and elsewhere of new historiographic and biographical materials, it is now possible to discern broad patterns in the calculation of Mi la ras pa's dates. Several of these are by now well established in Tibet and the west, but I also highlight here conventions that were promoted by eminent Bka' brgyud historians in the past but remained in relative obscurity both in and out of Tibet.

A comprehensive analysis of Mi la ras pa's chronology would need to rectify the dates in these sources with those recorded in the biographies of the yogin's students and contemporaries, a project beyond the scope of the present essay. Instead, I draw mainly on the works of Mi la ras pa's own biographical tradition together with a number of important religious histories that explicitly discuss the yogin's chronology. I have examined many of these sources in detail elsewhere, so I will identify them here only in brief. ${ }^{1}$ They consist of three general categories of texts: (1) what I refer to as the proto-rnam mgur, an early form of combined biography (rnam thar) and poetry

${ }^{1}$ Quintman (2014). 
anthology (mgur 'bum) focused on Mi la ras pa's life; (2) biographical compendia, comprehensive, extended, and often more literary accounts of the yogin's life; (3) miscellaneous works including religious histories (chos 'byung) and prayers (gsol 'debs).

The proto-rnam mgur works include compositions by Rgyal thang pa Bde chen rdo rje (ca. 13th century), Don mo ri pa (b. 1203), the second Zhwa dmar Mkha' spyod dbang po (1350-1405), and an extensive early treatment by Zhi byed ri pa (born ca. 1320). ${ }^{2}$ The biographical compendia consist of an interrelated cycle of extended works, beginning with the so-called Twelve Great Disciples (Bu chen bcu gnyis), whose authorship is ascribed to twelve of the yogin's close disciples, chiefly Ngan rdzong Byang chub rgyal po and Zhi ba 'Od. A series of increasingly complex biographies grew from this initial version during the fourteenth and fifteenth centuries, which came to be identified as The Black Treasury (Mdzod nag ma). These works were closely associated with the line of Karma pa hierarchs, particularly the third Karma pa Rang byung rdo rje (1284-1339), who is said to have played an editorial role in their production. ${ }^{3}$ Historical sources include the early rare Chos 'byung Mig 'byed 'od stong by Bsod nams rgyal mtshan dpal bzang po (1386-1434) written in 1418, the well-known Lho rong chos 'byung (1446-1451) and Deb gter sngon po (1478), as well as Si tu Pan chen's study of the Bka' brgyud tradition Nor bu zla ba chu shel. Another important source is the famous verse prayer to Mi la ras pa composed in 1448 by the hermit of La phyi Nam mkha' bsam grub rgyal mtshan (fifteenth century), who was a contemporary of Gtsang smyon Heruka, author of Mi la ras pa's best-known biography. A table of chronologies is presented in Table 1. The discussion concludes with an examination of a rare extended analysis of Mi la ras pa's dates, carried out by Kah thog Tshe dbang nor bu (1698-1755) who synthesizes many of the sources discussed here. A translation of the relevant section comprises the Appendix.

\footnotetext{
${ }^{2}$ For an analysis of Zhi byed ri pa's work, see Quintman (2012); Childs and Quintman (2012). Zhi byed ri pa's work is also available in several modern publications, listed in the bibliography.

${ }^{3}$ For an extended discussion of the Bu chen bcu gnyis and Mdzod nag ma literature, see Quintman (2014), especially chapter 3.
} 


\section{Mi la ras pa's Dates in Western Scholarship}

Before turning to the Tibetan sources, it will be helpful to first consider how Mi la ras pa's dates have been addressed in the scholarship of Europe and North America, which coalesced around two alternatives: $1040-1123$ or 1052-1135. Perhaps the first European scholar to address Mi la ras pa's chronology, albeit indirectly, was the Hungarian pioneer of Tibetan Studies Alexander Csoma de Körös, who published a chronological table from Sde Srid Sangs rgyas rgya mtsho's Vaidūrya dkar po in 1834. Sde Srid's work places Mi la ras pa's birth in the iron-dragon year corresponding to 1040, although Körös miscalculates the year as 1038 - an error that would linger in Mi la ras pa scholarship through the early twentieth century. ${ }^{4}$

More than three decades later, Moravian missionary H. A. Jäschke noted Milarepa is "without a doubt a historical person" active during the eleventh century, a statement based on Körös's publication of the Vaidūrya dkar po chronology. ${ }^{5}$ He repeated this claim in his Tibetan-English Dictionary published in 1881. In his study of a chapter from the Mi la'i Mgur 'bum, published the same year, Sarat Chandra Das places the yogin in the fourteenth century, although this may well be a misprint, since earlier in the essay he describes the source of his translation as a block print "said to be 800 years old.", While that statement is certainly an exaggeration, it is in accord with the general eleventh-century date for the yogin. ${ }^{7}$

William Rockhill was among the first non-Tibetan scholars to recognize the difficulty in ascertaining Mi la ras pa's dates. In his 1884 study of the Mi la'i mgur 'bum he notes, "The exact date of Milaraspa's birth seems to be uncertain," although he cites the (mistaken) year 1038 from Körös's publication of the Vaidūrya dkar $p^{8}{ }^{8}$ A decade later, W. A. Waddell would repeat this claim in his The Buddhism of Tibet or Lamaism, once again citing the Vaidūrya dkar

\footnotetext{
${ }^{4}$ de Körös (1834), 184. Although the body of the Sde Srid's work was written between 1683-5, the chronology indicates the number of years elapsed from various historical moments up to the year 1687. Sangs rgyas rgya mtsho records that 647 years have passed since Mi la ras pa's birth. See Sangs rgyas rgya mtsho, VDK, 48. On de Körös's error, see Vostrikov (1970), 126n372.

${ }^{5}$ Jäschke (1869), 543.

${ }^{6}$ Das (1881), 238.

${ }^{7}$ This observation is likewise noted in Rockhill (1884), ccvii.

${ }^{8}$ Rockhill (1884), ccvii.
} 
po chronology. ${ }^{9}$ Waddell also included a chart recording the yogin's birth and death as 1038-1122. ${ }^{10}$ These miscalculations were later echoed in the writings of Berthold Laufer, Graham Sandberg, and later Sir Charles Bell. ${ }^{11}$

In 1889, Das published another important chronological table, referred to as the Re'u mig, part of the Dpag bsam ljon bzang by Sum pa mkhan po Ye shes dpal 'byor (1704-1788), written in $1748 .{ }^{12}$ In line with Sangs rgyas rgya mtsho's calculations, the Re'u mig records Mi la ras pa's birth in the iron-dragon year of the first sexagenary cycle (1040). Yet, errors in calculation appeared once again when Das mistakenly converted the year to $1039 .{ }^{13}$ Their difficulty in establishing a Gregorian equivalent notwithstanding, these early scholars largely agreed upon an iron-dragon year (1040) for the yogin's birth. As early as the mid-fifteenth century, at least some Tibetan historians had likewise adopted the tradition of Mi la ras pa's birth in an iron-dragon year. That tradition, however, would be overshadowed in Tibet with the appearance of Gtsang smyon Heruka's version and in the west with its systematic study and translation.

Early translators of the Mi la'i rnam thar presented a different account of the yogin's dates, one introduced by the yogin's most famous biographer Gtsang smyon Heruka. In the introduction to his French translation of the rnam thar, published in 1925, Jacques Bacot merely comments that Mi la ras pa lived during the eleventh century, although in a note to the text he adds that the yogin's birth in a waterdragon year - as written in Gtsang smyon's text-corresponds to 1052. ${ }^{14}$ In his 1928 publication of The Life of Tibet's Great Yogi Milarepa, W. E. Evans-Wentz likewise avoids discussing the yogin's dates in his introduction, although his footnote to the water-dragon year states: "M. Bacot and the Translator [Dawa Samdup] agree in their calculation that Milarepa was born in the year AD 1052, but

\footnotetext{
${ }^{9}$ Waddell (1895), 65n4.

${ }^{10}$ Ibid., 66.

${ }^{11}$ See Bell (1931), 80; Laufer (1901), 2; (1902), 2; (1922), 7; Sandberg (1906), 250.

${ }^{12}$ Das (1889), 7.

${ }^{13}$ S. K. Jah calls Das's translation of the Re'u mig "negligent" in his forward to Bireshwar Prasad Singh's more recent translation, which itself contains many errors. See Singh (1991), xv.

${ }^{14}$ Bacot (1925), 45.
} 
according to Dr. Waddell's reckoning the year was AD 1038."15 Lobsang Lhalungpa concurs in his 1977 translation that the waterdragon year corresponds to $1052,{ }^{16}$ although he later incorrectly calculates that Mi la ras pa's death in a wood-hare year (as written by Gtsang smyon Heruka) corresponds to $1136 .{ }^{17}$

In his 1969 study of Gtsang smyon Heruka's Mi la narrative, Gene Smith noted that the madman likely introduced the 1052 birth year based upon the erroneous calculations of La phyi resident Nam mkha' bsam grub rgyal mtshan, in the latter's supplication to Mi la ras pa. This leads Smith to suggest, "we would do well to disregard the dates given by Gtsang smyon." 18

Perhaps most extensive treatment to date appears in Peter Roberts's study of Ras chung pa's biographical tradition, although at the time of writing he did not have access to many of the sources incorporated into the analysis here. ${ }^{19}$

\section{The Biographical Sources}

The early Tibetan sources present an even more complex picture of Mi la ras pa's dates. Writing in the thirteenth century, Rgyal thang pa records Mi la's birth in a sheep year, and death in a monkey year. He dies in his 73rd year and thus has a life span significantly shorter than any others in the tradition. ${ }^{20}$ These animal years suggest the dates 1031-1104, 1043-1116, or 1055-1128. In terms of both dates and lifespan, Rgyal thang pa's record appears to be an outlier.

Rgyal thang pa's contemporary Don mo ri pa describes Mi la ras pa's death as taking place on the 8th day of the 4th month of a bird year, with a life span of 82 years. ${ }^{21}$ This would place his birth in a rat year and suggests the possible dates 1024-1105, 1036-1117, or 10481129. The early compendia generally agree with the rat-year birth although they diverge in terms of the death-year and lifespan. A bird-

\footnotetext{
${ }^{15}$ Evans-Wentz (1928), 52n4.

${ }^{16}$ Lhalungpa (1977), 208n9.

${ }^{17}$ Ibid. 219n14.

${ }^{18}$ Smith (2001), 288n175.

${ }^{19}$ See Roberts (2007).

${ }^{20}$ Rgyal thang pa, JGM, 198, 260.

${ }^{21}$ Don mo ri pa, JMN, 215.
} 
year death also agrees with Zhi byed ri pa's calculations, a tradition discussed below.

Turning to the biographical compendia, the Bu chen bcu gnyis and Mdzod nag ma-Lhasa that largely copies it both record Mi la ras pa's death as occurring on the 15th day of a tiger (1st) month in a hare year, with a life span of 88 years. ${ }^{22}$ Although neither text records a specific birth, it must occur in a rat year. These dates are echoed in the Mdzod nag ma-RD, which was produced somewhat later. ${ }^{23}$ The Mdzod nag ma-BL explicitly states that the yogin was born in a rat year. ${ }^{24}$ This suggests plausible dates of 1024-1111, 1036-1123, or 1048-1135.

The Mdzod nag ma-I and -S change the animal and add the element for Mi la's birth, specifying that it took place in a waterdragon year, but maintain the tradition of his death in a hare year. ${ }^{25}$ Although they further maintain a life span of 88 years, this does not agree with the text's stated birth and death years, which should be calculated as consisting of either 72 or 84 years. Thus, the birth must take place in 1052, and the death in either 1123 or 1135 . According to a brief history of the Mdzod nag ma text cycle, the yogin was 82 in a water-ox year (1133) a few years before death. ${ }^{26}$ This suggests the dates 1052-1135, constituting the latter lifespan of 84 years. These discrepancies may be a product of the text's rather late and composite nature.

Zhi byed ri pa's calculations, carried out in the late fourteenth century, are some of the most perplexing. He notes that the yogin was born on the 14th day of the 10th month of a tiger year, and later states that he died on the 14th day of the tiger month of a bird year, at the age of $84 .{ }^{27}$ This chronology (i.e., between a tiger and bird year) would normally account for only an 80-year life span.

With the birth in a tiger year birth and death in a bird year, the dates must be 1026-1105 for the following reason. Zhi byed ri pa records that he completed his text in a water-ox year, which must correspond to 1373, and further notes this took place 269 years after

\footnotetext{
${ }^{22}$ BCO, 186a; BCN, 235b; DNM-L, 297a.

${ }^{23}$ DNM-RD, 750.5 .

${ }^{24}$ DNM-BL, 2a.

${ }^{25}$ DNM-I, 8, 532; DNM-S, 2a, 310a.

${ }^{26}$ DNM-D, 513.

${ }^{27}$ Zhi byed ri pa, NDO, 1, 40.
} 
Mi la ras pa's passing. This corresponds to a death in 1105, and thus a birth in 1026, a fire-tiger year. Kah thog rigs 'dzin Tshe dbang nor bu later records Zhi byed ri pa's position as affirming birth in a fire-tiger year (1026) by adding the element. Zhi byed ri pa's death in a bird year is only one year after Rgyal thang pa's record of a monkey year; this is notable since Zhi byed ri pa places the death only two weeks after the new year changed from a monkey to a bird.

The fifteenth century witnessed a growing concern for precision, if not consistency, in the recording of Mi la ras pa's dates as authors begin to cite both animal and element constituent. The rare religious history Chos 'byung mig 'byed 'od stong, completed in 1418 by Bsod rnams rgyal mtshan dpal bzang po is illustrative of these concerns ${ }^{28}$ This work records the yogin's birth in a water-dragon year (1052) and his death in a water-hare year (1123), with a lifespan of 84 years. ${ }^{29}$ The influential Bka' brgyud histories Lho rong chos 'byung (completed 1446-1451) and Deb gter sngon po (completed 1478), both appearing in the decades leading up to Gtsang smyon's version, provide an alternate tradition of Mi la ras pas birth. These works record the birth taking place in an iron-dragon year (1040) and death in a water-hare year (1123), yet with the similar lifespan of 84 years. ${ }^{30}$ The Lho rong chos 'byung's author Tshe dbang rgyal adds a note stating: "If it were the case that [Mi la] was born in a male waterdragon year (1052) and died in his 84th year in a male wood-hare year (1135), then it would not have been possible for Lord Dwags po to have met him at age fifty-five, as is also the case for Tshe ring ma and several others." ${ }^{31}$ This comment perhaps refers to the tradition previously established by the Mig 'byed 'od stong. The Lho rong chos 'byung's author Tshe dbang rgyal also states that from the time of Mi la's birth up to the time of writing in 1446 (a fire-tiger year), six sexagenary cycles and an additional forty-seven years (a total of 417 years) had passed, further pointing to a birth in $1040 .{ }^{32}$

\footnotetext{
${ }^{28}$ For background on the text and its author, see Sørensen and Dolma (2007), 15-19.

${ }^{29}$ Ibid., 64-5.

${ }^{30}$ LRC, 72, 100; Roerich (1949), 427, 436.

${ }^{31}$ LRC, 100. cho pho 'brug la 'khrungs nas gya bzhi shing mo yos la gshegs pa'i dbang du yin nal rje dwags po nga lnga la mjal ba dang tshe ring ma sogs 'ga' mi 'grigs par 'dug

${ }^{32}$ Ibid., 107.
} 
At about the same time however, Nam mkha' bsam grub rgyal mtshan, author of the famed Mi la encomium, seems to affirm the dates provided in the Mig 'byed 'od stong three decades earlier, noting that the yogin passed into the land of Akaniștha at the age of eightyfour, in the horse month of a wood-hare year, corresponding to 1135 . $^{33}$ He further corroborates this date by noting in the colophon that he completed the text in 1448 (an earth-dragon year), 314 years after Mi la ras pa's death, which indeed corresponds to $1135 .{ }^{34}$ With a life span of 84 years, this would place the yogin's birth in the water-dragon year corresponding to 1052. Gtsang smyon Heruka later incorporated these dates in his standard version of Mi la ras pa's life, either from the Mig 'byed 'od stong or perhaps from Nam mkha' sam grub rgyal mtshan who he met at La phyi. ${ }^{35}$ Writing in the mid-sixteenth century, acclaimed Bka' brgyud historian Dpa' bo Gtsug lag phreng ba (15041566) makes no mention of the yogin's birth or death year, but rather notes simply that Mi la ras pa "departed for Abhirati in his eightyfourth year" following a lifespan tradition that had been established a century earlier. $^{36}$

In 1742, Kah thog rigs 'dzin Tshe dbang nor bu composed a treatise analyzing the dates of several important early Tibetan figures including Atisha, Mar pa, Rngog Chos kyi rdo rje, and Mi la ras pa. ${ }^{37}$ The text was later revised and expanded in 1746 and provides a rare example of an extended analysis of Mi la ras pa's dates by a Tibetan historian. Tshe dbang nor bu identifies four chronological traditions for the birth of Mi la ras pa, largely distilling the dates found in sources discussed above:

1. water-dragon year (1052)

2. iron-dragon year (1040)

3. fire-tiger year (1026)

4. earth-dragon year (1028)

\footnotetext{
${ }^{33}$ Nam mkha' bsam grub rgyal mtshan, 6a.

${ }^{34}$ Ibid, 7 a.

${ }^{35}$ On Gtsang smyon's meeting with Nam mkha' bsam grub rgyal mtshan, see Rgod tshang ras pa, TNG, $105 \mathrm{ff}$.

${ }^{36}$ Gtsug lag phreng ba KGT, 783.

${ }^{37}$ For an analysis of Tshe dbang nor bu's chronology of the Bi ma snying thig transmission, see Prats (1984).
} 
The first tradition, birth in a water-dragon year (1052) is followed by the Mig 'byed 'od stong, Nam mkha' bsam grub rgyal mtshan, and Gtsang smyon Heruka; the second, birth in an iron-dragon year (1040) by the Lho rong chos 'byung, and Deb gter sngon po. Tshe dbang nor bu discounts both of these traditions as untenable for reasons of inconsistency with the dates of Mi la's disciple Sgam po pa. For the third tradition, based on Zhi byed ri pa's calculation, he adds the element constituent, identifying the birth in a fire-tiger year (1026). Tshe dbang nor bu acknowledges this not far from his own position.

Finally, he identifies a fourth tradition, birth in an earth-dragon year (1028), which he accepts as the most tenable possibility. He notes that in general, many earlier biographies likewise record a dragon year birth; this is no doubt a reference to nearly every major biographical and historical work from the mid-fourteenth century on. Moreover, Tshe dbang nor bu states, "the year of Lord Myi la's birth [i.e., in 1028] should be accepted according to Glorious Mkha' spyod dbang po's view of Rang byung zhabs' oral tradition." ${ }^{38}$ Although the second Zhwa dmar Mkha' spyod dbang po's version does not record dates for Mi la ras pa's birth or death, he is here described as following Rang byung rdo rje's view. With a lifespan of eighty-four years, this tradition would locate the death in an iron-hare year (1111). And indeed, the Bu chen bcu gnyis, together with most of the early texts in the Mdzod nag ma cycle - which seem to have been influenced by the editorial hand of Rang byung rdo rje - maintain the yogin's death in a hare year. ${ }^{39}$ As confirmation of this, Tshe dbang nor bu cites Mkha spyod dbang po from an unnamed source: "In an earth-ox year (1109), when Sgam po pa was thirty-one, he met Mi la. At the end of an ironhare year (1111), when [Sgam po pa] was thirty-four, Mi la died peacefully." 40

The tradition of birth in an earth-dragon year (1028) apparently supported by Rang byung rdo rje and Mkha' spyod dbang po, as well as Tshe dbang nor bu-is repeated several decades later in a supplement to the Zla ba chu shel, an extended history of the Karma

\footnotetext{
${ }^{38}$ See Tshe dbang nor bu, SDN1, 694. des na rje myi la'i 'khrungs lo rang byung zhabs kyi gsung rgyun dpal mkha' spyod dbang po'i bzhed pa ltar khas blang par bya stel

${ }^{39}$ The record of a rat-year-birth in those texts, as opposed to a dragon year favored by Tshe dbang nor bu, is accounted for by the longer lifespan of 88 years.

${ }^{40}$ Tshe dbang nor bu, SDN1, 650.
} 
Bka' brgyud tradition by Si tu Pan chen Chos kyi 'byung gnas (17001774) and 'Be lo tshe dbang kun khyab (b. 1718). ${ }^{41}$ Chos kyi dbang phyug (1775-1837) likewise agrees with this date in his history of Brag dkar rta so monastery. ${ }^{42}$

\section{Conclusions}

The preceding chronological traditions can be summarized in the following way, broadly based on a scheme posited by Tshe dbang nor bu. In general, the dates of the earliest biographical writings, including works by Rgyal thang pa and Don mo ri pa, show little uniformity. Most early compendia, including the Bu chen bcu gnyis and Mdzod nag $m a$, lack an element making precise calculations difficult. But they tend to fall within a general range of dates and lifespan that would be adopted by later works. We find, for example, a preference for recording Mi la's death in a hare year that would be adopted by later traditions. Tibetan biographers and historians eventually formulated three main traditions. Each of these place Mi la's birth in a dra-gon year and his death in a hare year, but they change the elements to span three different twelve-year cycles. The three traditions can be summarized as follows.

Early Tradition. Kah thog rig 'dzin Tshe dbang nor bu proposes the early tradition of dating (1028-1111), purported to be the oral traditions of Rang byung rdo rje and Mkha' spyod dbang po, and not far from Zhi byed ri pa's dates. It is possible that the discrepancies between Zhi byed ri pa and Tshe dbang nor bu might be worked out in the following way. First, Mi la ras pa's death at 84 would correspond to age 83 in Western reckoning, since Tibetans are generally considered to be one year old at birth. Moreover, (1) the Tibetan lunar new year and the western solar new year can diverge by as much as two months; (2) Tibetans generally consider their age to change at the time of the new year; (3) they reckon that a full year has passed from a given date once the new year is reached, regardless of how much calendrical time has actually passed; and (4) Zhi byed ri pa records Mi la ras pa's birth as occurring late in the year and his death very early in the year. With these points in mind, it is possible to fit several

\footnotetext{
${ }^{41}$ Si tu Pan chen Chos kyi 'byung gnas \& 'Be lo tshe dbang kun khyab, CSK, 69.

${ }^{42}$ Chos kyi dbang phyug, DTL, $13 b$.
} 
"additional" years into Zhi byed ri pa's time frame. ${ }^{43}$ It is interesting to note that renowned Tibetan scholars including Si tu Pan chen Chos kyi 'byung gnas and his disciple Be Lotsāwa, as well as the Brag dkar rta so incarnation Chos kyi dbang phyug, followed Tshe dbang nor bu's view, thus carrying the "early tradition" of dating well into the nineteenth century. ${ }^{44}$

Middle Tradition. The Bka' brgyud historians Tshe dbang rgyal (in his Lho rong chos 'byung) and 'Gos Lotsāwa Gzhon nu dpal (in his Deb gter sngon po) advance those dates one twelve-year cycle, forming the middle tradition of dating (1040-1123), a position repeated by Sde srid Sangs rgyas rgya mtsho and Sum pa mkhan po al-though largely rejected by later Bka' brgyud historians. This is also the tradition followed in many contemporary publications both in Tibet and the West.

Late Tradition. Finally, and perhaps following the examples of the Mig 'byed 'od stong, DNM-I, and DNM-S, Nam mkha' bsam grub rgyal mtshan and Gtsang smyon Heruka advance these dates yet another twelve year cycle (1052-1135), forming the late tradition of dating.

Even as there was little consensus about Mi la ras pa's dates or lifespan, several authors acknowledged the variety of competing calendrical traditions stemming from both Tibetan and Chinese systems of astrology, and incorporating local and regional conventions as well. Zhi byed ri pa writes,

Some people say that the Great Rje btsun's birth sign is without doubt a tiger year, that without doubt he died in a bird year, and that between those dates only eighty-two years passed. But in the estimation of the Dharma Lord Zhang Lotsāwa Grub pa dpal bzang, who is unmistaken regarding the five branches of knowledge, there is a difference between Chinese astrology and Tibetan astrology as well as earlier and later traditions (snga shul, phyi shul?), and so in truth between his birth and death, there is no room for doubt that eightyfour years passed, with a day [being calculated according to] two astrological systems. This accords with the untainted sayings of the Great Rje btsun himself as well as the great disciples of Ras chung pa Rdo rje grags and so forth-in particular, Khyung tshang pa Prajñāguru, his great disciples Khams pa Dar ma dpal, Mnga' ri pa Ye

\footnotetext{
${ }^{43}$ See, for example, Yamaguchi (1984).

${ }^{44}$ See Si tu Pan chen, CSK, 69, 79; Chos kyi dbang phyug, DKS, 22a, 25a.
} 
shes grags pa, Ma cig 'ong jo, Mar ston Tshul 'byung, and Stad sgom Zhib po lo gros. ${ }^{45}$

In his survey, Tshe dbang nor bu also mentions the possibility of alternative systems of calculation. Although he notes that Ngan rdzong ras pa records Mi la ras pa's encounter with the five long life sisters occurring in a water-dragon year (1112), he argues that the element of that year must be mistaken, and was perhaps calculated (by Ngan rdzong) on the basis of a Chinese system. ${ }^{46}$

In calculating the number of years $\mathrm{Mi}$ la ras pa spent meditating at Brag dkar rta so, Chos kyi dbang phyug notes another, apparently regional chronological system:

In one view, eighteen "valley years" [is equivalent to] to eighteen years in our own system, but this is mistaken. What is the use of counting valley years when it should be cited using Tibetan years. A valley year is calculated as half a [normal] year in which each month has only fifteen days, and this makes eighteen [valley years]. In actuality, he spent nine human years, and there is no alternative. ${ }^{47}$

Perhaps access to new sources and further investigation will allow us to determine Mi la ras pa's dates with greater confidence. For now, as with so many elements of the great yogin's life, a precise account of his birth and death remains out of reach.

\footnotetext{
${ }^{45}$ Zhi byed ri pa, NDO, 46 .

${ }^{46}$ Tshe dbang nor bu, SDN, 694. Ngan rdzong's statement is recorded in the early compendia as well as Gtsang smyon's later standard version. However, Gtsang smyon also included specific dates for the next two Tshe ring ma cycles so that they follow in sequential years, first a water-snake (1113) and then a wood-horse (1114). See Gtsang smyon Heruka, NG, 468, 491; Chang (1962), 313, 334. For these two cycles, the early compendia include only the month and day, and not the year, so it seems that Gtsang smyon Heruka himself added those dates. See BCO, 130a, 137a; DNM-S, 169.8, 184.7 .

${ }^{47}$ Chos kyi dbang phyug, DTL, 20.
} 


\section{Table 1}

Parenthetical dates are not explicitly mentioned in the text, but were calculated based on the given lifespan.

\begin{tabular}{|c|c|c|c|}
\hline Source & Possible Dates & Tibetan Date & $\begin{array}{l}\text { Life- } \\
\text { span }\end{array}$ \\
\hline $\begin{array}{l}\text { Rgyal thang pa, } \\
\text { JGM } \\
\text { (13th century) }\end{array}$ & $\begin{array}{l}1031-1104 \\
1043-1116 \\
1055-1128\end{array}$ & $\begin{array}{l}\text { B: sheep year } \\
\text { D: 3rd month of a monkey year }\end{array}$ & 73 \\
\hline $\begin{array}{l}\text { Don mo ri pa, } \\
\text { JMN } \\
\text { (ca. 1245) }\end{array}$ & $\begin{array}{l}(1024)-1105 \\
(1036)-1117 \\
(1048)-1129\end{array}$ & $\begin{array}{l}\text { B: (rat year) } \\
\text { D: } 8 \text { th day of the } 4 \text { th month of a } \\
\text { bird year }\end{array}$ & 82 \\
\hline $\begin{array}{l}\text { Bu chen bcu } \\
\text { gnyis } \\
\text { ca. } 1150-1250\end{array}$ & $\begin{array}{l}(1024)-1111 \\
(1036)-1123 \\
(1048)-1135\end{array}$ & $\begin{array}{l}\text { B: (rat year) } \\
\text { D: } 15 \text { th day of tiger month of a } \\
\text { hare year }\end{array}$ & 88 \\
\hline $\begin{array}{l}\text { Mdzod nag ma- } \\
\text { Lhasa } \\
<1339\end{array}$ & $\begin{array}{l}(1024)-1111 \\
(1036)-1123 \\
(1048)-1135\end{array}$ & $\begin{array}{l}\text { B: (rat year) } \\
\text { D: } 15 \text { th day of tiger month of a } \\
\text { hare year }\end{array}$ & 88 \\
\hline $\begin{array}{l}\text { Mdzod nag ma- } \\
\mathrm{RD}\end{array}$ & $\begin{array}{l}(1024)-1111 \\
(1036)-1123 \\
(1048)-1135\end{array}$ & $\begin{array}{l}\text { B: (rat year) } \\
\text { D: } 15 \text { th day of tiger month of a } \\
\text { hare year. }\end{array}$ & $88^{48}$ \\
\hline $\begin{array}{l}\text { Mdzod nag ma- } \\
\text { BL }\end{array}$ & & B: rat year & \\
\hline $\begin{array}{l}\text { Mdzod nag ma- } \\
\text { I/S } \\
\text { ca. } 1373-1450\end{array}$ & $1052-1123 / 1135$ & $\begin{array}{l}\text { B: water-dragon } \\
\text { D: hare year }\end{array}$ & $\begin{array}{l}88 \\
(72 / \\
84)^{49}\end{array}$ \\
\hline $\begin{array}{l}\text { Mkha' spyod } \\
\text { dbang po, CBB } \\
(1350-1405)\end{array}$ & $1028-1111$ & $\begin{array}{l}\text { B: earth-dragon } \\
\text { D: iron-hare }\end{array}$ & 84 \\
\hline
\end{tabular}

${ }^{48}$ DNM-RD, 750.5. Text mistakenly writes "8."

${ }^{49}$ The text states that Mi la ras pa died in his eighty-eighth year, but the dates given for his birth and death only allow for a life span of 72 or 84 years.

${ }^{50}$ These dates are missing in Mkha' spyod dbang po's text but are given here based on the analysis of Kah thog Tshe dbang nor bu. 


\begin{tabular}{|c|c|c|c|}
\hline $\begin{array}{l}\text { Zhi byed ri pa, } \\
\text { NDO } 1373\end{array}$ & $1026-1105$ & $\begin{array}{l}\text { B: } 14 \text { th day of the } 10 \text { th month of a } \\
\text { tiger year } \\
\text { D: } 14 \text { th day of the tiger month of a } \\
\text { bird year }\end{array}$ & $84^{51}$ \\
\hline $\begin{array}{l}\text { Bsod nams rgyal } \\
\text { mtshan dpal } \\
\text { bzang po, MBO } \\
1418\end{array}$ & $1052-1135$ & $\begin{array}{l}\text { B: water-dragon year } \\
\text { D: horse month of wood-hare year }\end{array}$ & 84 \\
\hline $\begin{array}{l}\text { Lho rong chos } \\
\text { 'byung } \\
1446-1451\end{array}$ & $1040-1123$ & $\begin{array}{l}\text { B: iron-dragon } \\
\text { D: 14th day of horse month of } \\
\text { water-hare }\end{array}$ & 84 \\
\hline $\begin{array}{l}\text { Nam mkha bsam } \\
\text { grub rgyal mtshan, } \\
\text { MSD } 1448\end{array}$ & (1052)-1135 & $\begin{array}{l}\text { B: (water-dragon) } \\
\text { D: horse month of wood-hare }\end{array}$ & 84 \\
\hline $\begin{array}{l}\text { Deb gter sngon } \\
\text { po } 1478\end{array}$ & $1040-1123$ & $\begin{array}{l}\text { B: iron-dragon } \\
\text { D: water-hare }\end{array}$ & 84 \\
\hline $\begin{array}{l}\text { Gtsang smyon } \\
\text { Heruka } 1488\end{array}$ & $1052-1135$ & $\begin{array}{l}\text { B: water-dragon } \\
\text { D: wood-hare }\end{array}$ & 84 \\
\hline $\begin{array}{l}\text { Ba'i dūrya dkar } \\
\text { po, Sde srid } \\
\text { Sangs rgyas rgya } \\
\text { mtsho } \\
1683-1685\end{array}$ & b. 1040 & B: iron-dragon & \\
\hline $\begin{array}{l}\text { Kah thog Tshe } \\
\text { dbang nor bu } \\
1698-1755\end{array}$ & $\begin{array}{l}\text { (1) 1052-(1135) } \\
\text { (2) 1040-(1123) } \\
\text { (3) 1026-(1109) } \\
\text { based on Zhi } \\
\text { byed ri pa } \\
\text { (4) 1028-1111 } \\
\text { based on Mkha' } \\
\text { spyod dbang po }\end{array}$ & $\begin{array}{l}\text { B: water-dragon } \\
\text { D: (wood-hare) } \\
\text { B: iron-dragon } \\
\text { D: (water-hare) } \\
\text { B fire-tiger } \\
\text { D: (earth-ox) } \\
\text { B: earth-dragon } \\
\text { D: iron-hare }\end{array}$ & 84 \\
\hline
\end{tabular}

${ }^{51}$ See discussion of Zhi byed ri pa's calculation of the lifespan above. 


\begin{tabular}{|l|l|l|l|}
\hline $\begin{array}{l}\text { Dpag bsam ljon } \\
\text { bzang, Sum pa } \\
\text { mkhan po Ye } \\
\text { shes dpal 'byor } \\
1748\end{array}$ & b. 1040 & B. iron-dragon & \\
\hline $\begin{array}{l}\text { Si tu/Be lo Kha } \\
\text { skol ma } 1775\end{array}$ & $1028-(1111)$ & $\begin{array}{l}\text { B: earth-dragon } \\
\text { D: (iron-hare) }\end{array}$ & 84 \\
\hline $\begin{array}{l}\text { Brag dkar Chos } \\
\text { kyi dbang phyug } \\
1816\end{array}$ & $1028-1111$ & $\begin{array}{l}\text { B: earth-dragon } \\
\text { D: iron-hare }\end{array}$ & 84 \\
\hline
\end{tabular}

\section{Appendix}

A Pure and Brief Clarification: Seeds for a Definitive Discussion of the Chronologies in the Biographies of Several Excellent Masters Including Mar pa, Mi la, Dwags po, the Father Jo bo rje and his Spiritual Sons

Mar mi dwags po jo bo rje yab sras sog dam pa 'ga' zhug gi rnam thar sa bon dus kyi nges pa brjod pa dag ldan nyung gsal

by Kạ̣ thog rig 'dzin Tshe dbang nor bu (1698-1755)

Excerpt on Mi la ras pa's dates.

There are three traditions regarding the birth year of the powerful lord of adepts Mi la ras pa-principal holder of Rje btsun Mar pa's teachings of the essential truth, source of the entire practice lineage, ear ornament of the snowy land of Tibet: that it was a water-dragon year (1052), an iron-dragon year (1040), or an earth-dragon year (1028). There is also the tradition of Zhi byed ri pa, famed for having seen 127 versions of Mi la's life story, who states that it was a tiger year. This was a fire-tiger (1026), which was two years before the earth-dragon. Following the fire-tiger was the fire-hare (1027), which corresponds to the [beginning of the] first sexagenary calendrical cycle. Thus there are four different dates. 
The assessment of his birth in a water-dragon year (1052) is untenable due to numerous inconsistencies, such as the following. Ngam rdzong ston pa has said that the events of the first great dialogue and magical display of the demon horde at $\mathrm{Chu}$ dbar occurred during a water-dragon year (1112). This seems to correspond to the period when Mi la was in his sixty-first year. However, it is certain that Sgam po pa met Mi la in an earth-ox year (1109), when the former was thirty-one. Therefore, according to this system of dating, he would have had to have met Mi la when the latter was fiftynine. Since twenty-six years would have passed between then and when Mi la died, it is implausible that he would not have met Mi la during that timespan. While everyone accepts Sgam po pa as the last disciple, the meetings by Ras chung pa and Sgam po pa would have occurred at exactly the same time, except for minor variations in their chronology. There is also [Mi la ras pa's] statement [to Sgam po pa], "Come to the mountain of 'Brim Chu dbar next year in the horse month of the hare year (1111)."

The assessment of his birth in an iron-dragon year (1040) is more tenable than the previous one. However, if we accept that Mi la died twelve years after meeting Sgam po pa, [the statement above would instead be] "Come to the mountain of Brim in twelve years," changing "next year" to "in twelve years." This would make it seem to temporarily agree. However, it is said that after Sgam po pa met Mi la, he served him for one year and one month, or nineteen months. ${ }^{52}$ In any case, he traveled to Dbus when he was thirty-two, and stayed there for one year. While there, he remembered that the Rje btsun said, "Come to the Chu dbar mountain in Brim next year in the horse month (rta sa zla?) of the hare year." Then, while on the road, he heard that Mi la had died and he scattered gold in the direction of Brim and sang a song of grief. I have seen this in an uncorrupted old manuscript version of Sgam po pa's biography written by a direct disciple who states, "I have written this without adding anything or leaving anything out." Examining the content of Sgam po pa's other biographies as well, this seems to correspond to the facts. For this reason, since the tradition [counting his birth in an iron-dragon year (1040)] does not agree with this [evidence], it is not tenable.

\footnotetext{
${ }^{52}$ UNSURE: lo gcig dang zla bag cig drung du bsnyen khig nas zla ba bcu dgu brten yang zer
} 
Regarding the assertion that he was born in an earth-dragon year (1028), Dpal Mha' zpyod dbang po has said, "Sgam po pa met Mi la in an earth-ox year (1109), when he was thirty-one. At the end of an iron-hare year (1111), when he was thirty-four, Mi la passed away. The year before that, an iron-tiger year (1110), Lord Dus gsum mkhyen pa was born." The earlier and later dates agree and I believe they very much correspond to the facts. One may wonder whether the calculation that Tshe ring ma's question and answer [session with Mi la ras pa] took place in a water-dragon year (1112) disagrees with [this this assessment]. In general, several authentic teachers have said, "the element (khams) of that date is wrong," a statement that corresponds to the facts. Moreover, it is also possible that the claim [regarding the water-dragon year] was made by counting the month and year according to the system of "mother and son elements," as in China. ${ }^{53}$ It is, therefore, a topic for further examination.

There are not many years difference between the assertions that he was born in an earth-tiger year (1026) [a claim made by Zhi byed ri pa] and an earth-dragon year (1028), so generally speaking, they do not contradict one another. Nevertheless, even though the biographies as a whole typically disagree about the element (khams), only a dragon year appears. And when determined according to the tradition how Sgam po pa met [Mi la ras pa], a dragon year is also tenable. Consequently, Lord Mi la's birth year should be accepted according to the assertion of Dpal Mkha' spyod dbang po [i.e., an earth-dragon year, 1028], which is Rang byung zhabs's oral transmission.

Furthermore, Mi la's birthplace was Shod rtsa in Stod Mnga' ris gung thang. In the first part of his life, up until the age of thirty-seven, he served Rdo rje gnub chung, G.yung ston khro rgyal, and Rong ston lha dga; and then became proficient in the wrathful mantra practices and received the traditions of 'Jam dpal gshin rje gshed, Sgyu 'phrul, and in particular the Rdzogs chen sems phyogs as well as other secret instruction cycles. At that point, based upon a prophecy made by Rong ston lha dga', at the age of thirty-eight he met Mar pa and pleased the guru through his three gates. On one occasion, at the insistence of the guru's wife, he visited Rngog ston in Gzhung and stayed for a little more than half a year receiving oral instructions.

\footnotetext{
53 rgya nag ltar lo zla 'byung khams ma bur bsgrang ba. On the differentiation of the terms 'byung and khams in this context, see Henning (2007), 163.
} 
Apart from that, until he departed for retreat in the mountains, he relied on [his guru] like a body and its shadow for six years and eight months.

From the time he turned thirty-eight until he turned forty-four, he suffered abuse for more than four full years; and for two years, from forty-five until he turned forty-seven, he was uplifted by oral instructions. Having been accepted as a disciple, he stayed five or six years developing his capacity in the paths of maturation and liberation. Thereafter, he departed alone for mountain retreat with the strict vow to practice in accordance with the guru's command. After seven or eight years had passed, just when he turned fifty-four, Mar pa died. The following year, when he was fifty-five, nine years of his vow to practice has gone by. Then he upheld the victory banner of practice at La phyi, Chu dbar, Ti se and other unfixed locations, and then established an inconceivable number of humans and non-humans in the paths of maturation and liberation. Finally, in an iron-hare year (1111), at the age of eighty-four, he displayed the act of passing away together with an array of miracles.

\section{Tibetan Language Sources}

DNM-D Mi la'i gsung mgur mdzod nag ma. Khren tu'u: si khron mi rigs dpe skrun khang, 2008. 2 vols. Also published in 'Bri gung bka' brgyud chos mdzod chen mo. Lhasa: S.N., 2004. vols. 7-8.

DNM-BL No title. [Unique edition of the Mdzod nag ma.] Manuscript in the archives of the British Library. Shelfmark OR 16756.

DNM-I Rnal 'byor gyi dbang phyug mi la bzhad pa rdo rje'i gsung mgur ma mdzod nag ma zhes pa ka rma pa rang byung rdo rjes phyog bcig. Dalhousie: Damchoe Sangpo. 1978. 2 vols.

DNM-L Rje btsun mi la rdo rjre rgyal mtshan gyi rnam par thar pa'i dbu phyogs lags. Dbu med manuscript in the archives of 'Bras spung Monastery. 'Bras spung dkar chag: phyi ra 42, 017082, 309 folios.

DNM-RD“Mi la bzhad pa rdo rje'i gsung mgur mdzod nag ma zhes pa karma pa rang byung rdo rjes phyogs gcig tu bkod pa." In Karma pa rang byung rdo rje'i gsung 'bum. Zi ling: Mtshur phu mkhan po lo yag bkra shis, 2006. Vol. ga, 5-778. 
DNM-S Cover title: Rje rnal sbyor gyi dbang phyug dpal bzhad pa'i rdo rje'i 'gur 'tshogs tshad phyogs gcig du bsgrig pa lo rgyus kyis sbas pa zhes bya ba bzhugs so. Unpublished dbu med manuscript in the collection of E. Gene Smith.

Bsod nams rgyal mtshan dpal bzang po (1386-1434)

MBO Chos 'byung Mig 'byed 'od stong. Published in Sørensen and Dolma 2007.

Chos kyi dbang phyug, Brag dkar rta so sprul sku (1775-1837)

DTL Grub pa'i gnas chen brag dkar rta so'i gnas dang gdan rabs bla ma brgyud pa'i lo rgyus mdo tsam brjod pa mos ldan dad pa 'i gdung sel drang srong dga' ba'i dal gtam zhes bya ba bzhugs so. Written in 1816. Microfilm. Kathmandu, Nepal. NGMPP reel no. 940/8, 52 folios.

Don mo ri pa (b. 1203)

JMN Rje btsun mi la'i rnam thar. In Rdo rje bdzes 'od, Bka' brgyud kyi rnam thar chen mo rin po che'i gter mdzod dgos 'byung gnas. Bir, India: D. Tsondu Senghe, 1985, pp. 176218.

Gtsang smyon Heruka (1452-1507)

NG Rnal 'byor gyi dbang phyug chen po mi la ras pa'i rnam mgur. Zi ling: Mtsho sngon mi rigs dpe skrun khang, 1981.

Gtsug lag phreng ba, Dpa' bo II (1504-1566)

KGT Dam pa'i chos kyi 'khor lo bsgyur ba rnams kyi bhung ba gsal bar byed pa mkhas pa'i dga' ston. 2 vols. Beijing: Mi rigs dpe skrun khang, 1986.

Nam mkha' bsam grub rgyal mtshan (fifteenth century)

MSD Mi la ras pa'i gsol 'debs. Gangs can grub pa'i gtso bo'i ngo mtshar gtam// thos na ya mtshan dad pa'i mig 'byed pa'i// mthong na ngo mtshar 'od 'phreng 'gyed pa 'dis// skal ldan dad gus can gyi dga' ston mdzod/. Written in 1448 at Bkra shis lhun grub chos grwa. 7 folios. N.p., n.d. Block print in the collection of the Beinecke Rare Book and Manuscript Library, Tibet Bernard 68.

Rgyal thang pa Bde chen rdo rje (ca. thirteenth century).

JGM Rje btsun gyi rgyal po mid la ras pa'i rnam thar. In Dkar brgyud gser 'phreng: A Thirteenth Century Collection of Verse Hagiographies of the Succession of Eminent Masters of the 'Brug-pa Dkar-brgyud-pa Tradition. Tashijong, India: Sungrab Nyamso Gyunphel Parkhang. 1973. 189-265. 
Mkha' spyod dbang po, Zhwa dmar II (1350-1405)

CBB Chos rje dpal ldan mi la ras chen gyi rnam par thar pa byin rlabs kyi sprin phung. In The Collected Writings (Gsun 'bum) of the Second Źwa-dmar Mkha'-spyod-dban-po. Gangtok, Sikkim, India: Gonpo Tseten. 1978. Vol. 1, pp. 188-317.

Sangs rgyas rgya mtsho, Sde srid (1653-1705)

VDK The Vaidūrya dkar po of sde-srid sans-rgyas-rgya-mtsho: The Fundamental Treatise on Tibetan Astrology and Calendrical Calculations. New Delhi: T. Tsepa Taikhang. 1972.

Si tu Pan chen Chos kyi 'byung gnas (1700-1774) \& 'Be lo tshe dbang kun khyap

CSK Karma kam tshang brgyud pa rin po che'i rnam par thar pa rab 'byams nor bu zla ba chu shel gyi phreng ba'i kha skong. In Si tu Chos kyi 'byung gnas kyi bka 'bum. Vol. Da. Kangra, India: Sherab Ling Institute. 1990.

Tshe dbang nor bu, Kah thog rigs 'dzin. (1698-1755)

SDN1 Mar mi dwags po jo bo rje yab sras sog dam pa 'ga' zhug gi rnam thar sa bon dus kyi nges pa brjod pa dag ldan nyung gsal. In Selected Writings of Kah thog Rig 'dzin Tshe dbang Nor bu. 6 vols. Darjeeling: Kargyu Sungrab Nyamso Khang. 1973. Vol. 1, pp. 669-705.

SDN2 Mar mi dwags po jo bo rje yab sras sog dam pa 'ga' zhug gi rnam thar sa bon dus kyi nges pa brjod pa dag ldan nyung gsal. In Kah thog rig 'dzin tshe dbang nor bu'i bka' 'bum. 3 vols. Beijing: Krung go'i bod rig pa dpe skrun khang. 2006. Vol 3, p.p., 640-656.

Zhi byed ri pa (born ca. 1320)

NDO Rje btsun mid la ras pa'i rnam par thar pa nyi zla'i 'od zer sgron ma. Manuscript. in the archives of 'Bras spung Monastery. 'Bras spungs dkar chag: phyi ra 72, 017188, $105 \mathrm{ff}, 45 \times 8 \mathrm{~cm}$. (pagination refers to computer print-out.) 


\section{Editions}

In 'Bri gung bka' brgyud chos mdzod chen mo. Lhasa: s. n. 2004. Vol. 9: 251-498.

In Dpal brtsegs bod yig dpe rnying zhib 'jug khang, Rje Btsun Mi la ras pa'i gsung 'bum. Beijing: Krung go'i bod rig pa dpe skrun khang, 2011. Vol. 5: 154-331.

\section{European Language Sources}

Bell, Charles. 1931. The Religion of Tibet. Oxford: Cambridge University Press.

Chang, Garma C. C. The Hundred Thousand Songs of Milarepa. New Hyde Park, N.Y.: University Books, 1962. Reprint (2 vols. in 1), Boston: Shambhala Publications, 1999.

Childs, Geoff and Andrew Quintman. 2012. "Marriage, Kinship, and Inheritance in Zhi byed ri pa's Account of Mi la ras pa's Early Life." Revue d'Etudes Tibétaines, no. 23: 43-49.

Csoma de Körös, Alexander. 1834. A Grammar of the Tibetan Language. Reprint ed. Budapest : Akadémiai Kiadó, 1984.

Das, Sarat Chandra. 1881. "Dispute Between a Buddhist and a Bonpo Priest for the Possession of Mount Kailāsa and the Laka Mānasa." In "Contributions on the Religion, History, \&c. of Tibet." Journal of the Asiatic Society of Bengal. 50, part 1:

206-11. Reprinted in The Religion and History of Tibet (Delhi: Cosmo Publications, 1988).

. 1889. "Life of Sum-pa Mkhan-po also styled Ye-ses dpal'byor, the author of Rehumig (Chronological Table)," Journal of the Asiatic Society of Bengal, vol. 58, Part 1, No. II pp, 3784.

Evans-Wentz, W. Y., ed. 1928. Tibet's Great Yogī Milarepa: A Biography from the Tibetan. London: Oxford University Press. $1^{\text {st }}$ paperback edition, 1969. 
Henning, Edward. Kālacakra and the Tibetan Calendar. New York: American Institute of Buddhist Studies, 2007.

Jäschke, H. A. 1869. "Proben aus dem tibetischen Legendenbuche: die hunderttausend Gesänge des Milaraspa." Zeitschrift der Deutschen Morgenländischen Gesellschaft. Leipzig. xxiii, 54358.

-1881. A Tibetan-English Dictionary. London: Routledge \& Keegan Paul. Reprint ed. 1972.

Laufer, Berthold. 1901. Zwei Legenden des Milaraspa. Archiv für Religionswissenschaft 4. Band: 1-44.

-1902. Aus den Geschichten und Liedern des Milaraspa. Wien.

-1922. Milaraspa: Tibetische Texte in Auswahl übertragen.

Hagen i. W. und Darmstadt: Folkwang Verlag. Lhalungpa, Lobsang P., trans. 1977. The Life of Milarepa. Boston:

Shambhala Publications. Reprint ed., 1984.

Quintman, Andrew. 2014. The Yogin and the Madman: Reading the Biographical Corpus of Tibet's Great Saint Milarepa. New York: Columbia University Press.

. 2012. "Between History and Biography: Notes on Zhi byed ri pa's Illuminating Lamp of Sun and Moon Beams, a FourteenthCentury Biographical State of the Field." Revue d'Etudes Tibétaines, no. 23: 5-41.

Rockhill, Woodville W. 1884. "The Tibetan 'Hundred Thousand Songs' of Milaraspa." Journal of the American Oriental Society XI, Proceedings: 207-211.

Sandberg, Graham. 1906. "The Poet Milaraspa." In Tibet and Tibetans: 250-272. London: Society for Promoting Christian Knowledge.

Singh, Bireshwar Prasad. 1991. The Chronology of Tibet: According to the Re'u-mig of Sum-pa-mkhan-po. Patna: Bihar Research Society.

Sørensen, Per K., and Sonam Dolma. 2007. Rare Texts from Tibet: Seven Sources for the Ecclesiastic History of Medieval Tibet. Bhairahawa: Lumbini International Research Institute. 
Smith, E. Gene. 1969. "Preface" to The Life of the Saint of Gtsang. New Delhi: Śata pitaka Series Indo Asian Literatures Volume 79. Reprinted in Smith 2001, 59-79.

2001. Among Tibetan Texts: History \& Literature of the Himalayan Plateau. Boston: Wisdom Publications.

Vostrikov, A. I. Tibetan Historical Literature. 1970. New Delhi: Indian Studies Past \& Present.

Waddell, Laurence A. 1979. Buddhism \& Lamasim of Tibet. New Delhi: Heritage Publishers. Original edition, 1 